\title{
GROWTH ENVIRONMENT AND BACTERIAL TOXICITY
}

\author{
A. D. Pearson* and D. C. Ellwood \\ Microbiological Research Establishment, Porton, nr Salisbury, Wiltshire SP4 OJG
}

THE toxicity of bacterial vaccines has several causes. One of the most important of these is the endotoxin found in the cell wall of Gram-negative bacteria. The composition of bacterial cell walls is phenotypically variable, and it is known that the cell wall of Aerobacter aerogenes varies with respect to endotoxin components (Ellwood and Tempest, 1972). These walls were examined for toxicity in mice and it was found that those grown quickly, with a mean generation time (MGT) of 1 hour, under carbon limitation were toxic (LD50 3.4 mg per 20-g mouse), whereas walls from organisms grown slowly (MGT of 7 hours) were effectively non-toxic (LD50 150.5 mg per 20-g mouse) as were walls of bacteria grown slowly under magnesium limitation (Pearson and Ellwood, 1972).

Bacterial vaccines are commonly preparations of whole organisms and we report in this article a study of the toxicity of cells of Escherichia coli grown at the same rate but under several different limitations.

\section{MATERIALS AND METHODS}

\section{Test strain and culture conditions}

Escherichia coli (strain MRE160) was grown in a Porton-type chemostat (Herbert, Phipps and Tempest, 1965) in media limited with respect to specific nutrients, e.g., glycerol (carbon), phosphorus $\left(\mathrm{PO}_{4}{ }^{3-}\right)$, nitrogen $\left(\mathrm{NH}_{3}\right)$, sulphur $\left(\mathrm{SO}_{4}{ }^{2-}\right)$, potassium $\left(\mathrm{K}^{+}\right)$and magnesium $\left(\mathrm{Mg}^{2+}\right)$, at a temperature of $35^{\circ} \mathrm{C}$ with the $p \mathrm{H}$ controlled at 6.5 and at a dilution rate of $\mathrm{D}=0.2 \mathrm{~h}^{-1}$, to give an MGT of 3.5 hours. The cultures were allowed to reach steady state conditions and the organisms were collected in an ice-cooled receiver. The cells were harvested by centrifugation $(30 \mathrm{~min}$. at $10,000 \mathrm{~g}$ ), washed twice with water and freezedried. For comparative purposes, batch-grown organisms were grown in Lab-lemco broth (Oxoid) on a reciprocating shaker and harvested at the end of the log phase.

\section{Toxicity test}

The toxicities were measured by a standardised mouse-toxicity test for the freeze-dried cells reconstituted in pyrogen-free saline and heated at $60^{\circ} \mathrm{C}$ for $30 \mathrm{~min}$. to kill the organisms, and also to destroy heat-labile toxic proteins. Graded doses of heat-killed organisms were injected in $0.5-\mathrm{ml}$ portions by the intraperitoneal route into groups of ten Porton white mice. Deaths were noted every 24 hours after injection and the totals recorded up to 21 days.

\section{Statistical analysis}

These data were analysed by a probit regression programme suitably modified to express the results as the dose giving a $50 \%$ mortality (LD50), the corresponding $95 \%$ confidence limits and the relative toxicities. The LD50 results are given in mg of whole cells per $20-\mathrm{g}$ mouse and the relative toxicities compared with the LD50 of the batch-grown preparation. All the tests were carried out at the same time so that these comparisons should be valid.

\section{RESULTS}

Whole-organism preparations of $E$. coli were cultured under eight different growthlimiting procedures at a dilution rate of $\mathrm{D}=0.2 \mathrm{~h}^{-1}$ to give a mean generation time of 3.5

Received 26 Nov. 1973; accepted 26 Jan. 1974.

* Present address: Public Health Laboratory, St Mary's General Hospital, Milton Road, Portsmouth PO3 6AQ.

J. MED. MICROBIOL.-VOL. 7 (1974) 
hours at a temperature of $35^{\circ} \mathrm{C}$ and at a $p \mathrm{H}$ of 6.5 . The results of the biological toxicity testing of these preparations are presented in the table. Glycerol-limited organisms were markedly more toxic than organisms grown in the complex conditions of batch culture. In this investigation, organisms grown under sulphur limitation were the least toxic. Growth limitation thus has a marked effect on the toxicity of this test organism when the growth rate is constant under the stated test conditions.

TABLE

Biological toxicity of whole-organism preparations of Escherichia coli grown with different growth-limiting factors

\begin{tabular}{l|rc}
\hline \multicolumn{1}{c|}{$\begin{array}{c}\text { Growth-limiting } \\
\text { factor }\end{array}$} & LD50* & $\begin{array}{c}\text { Relative } \\
\text { toxicities }\end{array}$ \\
\hline Batch culture & $11 \cdot 0(8 \cdot 8-14 \cdot 6)$ & 1.0 \\
Glycerol (carbon) & $6 \cdot 1(4 \cdot 9-7 \cdot 7)$ & $1 \cdot 8$ \\
Anaerobic growth & $8 \cdot 6(7 \cdot 1-10 \cdot 8)$ & $1 \cdot 3$ \\
Potassium & $9 \cdot 1(7 \cdot-11 \cdot 5)$ & $1 \cdot 2$ \\
Magnesium & $9 \cdot 8(8 \cdot-12 \cdot 6)$ & 1.1 \\
Phosphorus & $11.7(9 \cdot 6-14 \cdot 5)$ & 0.9 \\
Nitrogen & $12.3(10 \cdot 1-15 \cdot 3)$ & 0.9 \\
Sulphur & $17.6(13 \cdot 7-24 \cdot 3)$ & 0.6 \\
\hline
\end{tabular}

LD50 expressed in mg of freeze-dried washed bacteria per 20-g mouse (see Methods), with $95 \%$ confidence limits given in brackets.

\section{Discussion}

These results are similar to those obtained by Pearson and Ellwood (1972) in a previous study with $A$. aerogenes cell walls where glycerol limitation produced the most toxic preparation. Together, these results suggest that the growth rate and growth limitation may have a marked effect on the toxicity of organisms, and it should thus be possible to grow Gram-negative bacteria in such a way that they lose their toxicity. In the present investigation a marked reduction in the toxicity of a dead whole-cell preparation of $E$. coli was produced by growth limitation of sulphur at a mean generation time of 3.5 hours in comparison with organisms grown either under carbon limitation or in batch culture.

In this study no chemical analyses were undertaken. A more detailed investigation should include the estimation of carbohydrate, protein, phosphorus, 2-keto-3-deoxy-Dmanno-octonic acid (KDO), heptose and $\beta$-hydroxymyristic acid. However, the interpretation of the results of chemical analyses on whole-organism preparations would be difficult. A valid comparison of chemical composition and biological toxicity necessitates the use of a cell fraction such as a cell-wall preparation or lipopolysaccharide. It is known that the chemical composition of the wall content of Gram-negative bacteria varies with respect to the growth rate and growth limitation (Tempest and Ellwood, 1969), but it is not known whether these variations are matched by variations in biological toxicity.

This report gives the results of work on a single laboratory strain of $E$. coli. Further work is required to determine whether the finding reported here is valid for other strains of $E$. coli including fresh isolates that had not been sub-cultured over several years in the laboratory. A similar approach is required for the investigation of other Gram-negative bacteria. If the finding of reduced biological toxicity under specified constant conditions of growth rate and limitation is found to apply generally to bacterial populations, such an approach might lead to the preparation of less toxic bacterial vaccines.

\section{SUMMARY}

Growth limitation was shown to affect the toxicity of whole organisms of Escherichia coli (strain MRE160) as determined by an LD50 method with the Porton strain of mouse. 
Glycerol limitation produced the most toxic organisms and limitation of sulphur the least toxic. The findings are discussed as a possible approach to the preparation of less toxic bacterial vaccines.

We thank Professor P. Armitage of the London School of Hygiene and Tropical Medicine for undertaking the statistical analyses.

\section{REFERENCES}

Ellwood, D. C. AND Tempest, D. W. 1972. Effects of environment on bacterial wall content and composition. Adv. microb. Physiol., 7, 83.

Herbert, D., Phipps, P. J. ANd Tempest, D. W. 1965. The chemostat and instrumentation. Lab. Pract., 14, 1150.

Pearson, A. D. AND Ellwood, D. C. 1972. The effect of growth conditions on the chemical composition and endotoxicity of walls of Aerobacter aerogenes N.C.T.C.418., Biochem. J., 127, 72P.

Tempest, D. W. AND Ellwood, D. C. 1969. The influence of growth conditions on the composition of some cell wall components of Aerobacter aerogenes. Biotechnol. Bioengng, 11, 775. 